\title{
Implementation of Usability Testing Methods to Measure the Usability Aspect of Management Information System Mobile Application (Case Study Sukamiskin Correctional Institution)
}

\author{
Hafidz. Firdaus \\ Widyatama University, Bandung, 40125, Indonesia \\ Email: hafidz.firdaus@widyatama.ac.id \\ Azizah. Zakiah \\ Widyatama University, Bandung, 40125, Indonesia \\ Email: azizah.zakiah@widyatama.ac.id
}

Received: 09 June 2020; Accepted: 28 July 2020; Published: 08 October 2021

\begin{abstract}
The aim of this study is to measure the usability aspects of Management Information System mobile application in terms of effectiveness, efficiensy, and user satisfaction by using performance measurement techniques, usability questionnaires and retrospective think aloud. Management Information System application is an internal mobile application that has functions to exchange information, fill daily absences, apply for leave and fill in the daily work journal of the Ministry of Justice and Human Rights employees. Until today, the mobile application of Management Information System has not been evaluated yet using the level of usability. This research was conducted by measuring the level of effectiveness, efficiency, satisfaction and retrospective think aloud. Due to the limitations of this study, researcher only gains 20 respondents who were all employees of Sukamiskin Correctional Institution within questionnaire. In addition, respondents also filled out the questionnaire given. Based on the results obtained the effectiveness level reached $100 \%$ and all respondents expressed satisfaction with mobile application of Management Information System. But in terms of efficiency needs to be more improved. And the results of the retrospective think aloud are still some improvements from the features and reduction of icons that appear on the screen. The results showed that using performance measurements and retrospective think aloud techniques had a significant effect on user satisfaction in sukamiskin correctional institution. With these techniques also shows the level of employee ability to complete tasks in the application does not fail.
\end{abstract}

Index Terms: Usability, usability testing, usability evaluation, mobile application, e-government, performance measurement, retrospective think aloud.

\section{Introduction}

The usage of information technology has been developed rapidly nowadays making it easier every element of society doing their own activity [1]. One of the technologies is smartphone. It has various features to carry out various activity easily and support productivity[2]. The efficient of public service is important as national competitiveness. To improve those public services, each country in the world about to promote e-government [3]. E-government efficiency, increasing the function of transparency and accountability, easy and fast access to services, in addition to democracy and lower administrative costs. Through applications on smartphones, e-government can provide such as services, jobs, transportation services, food and goods delivery services and employee information services.

One example of an e-government mobile application that is used for the field of information services is the Management Information System by the Ministry of Law and Human Rights. This application is managed by the Ministry of Law and Human Rights Management Information System, which is an internal mobile application that functions to exchange information by all employees within the Ministry of Law and Human Rights of the Republic of Indonesia and is also used by employees in the Sukamiskin Correctional Institution.

Sukamiskin Correctional Institution is a Technical Implementation Unit under the Regional Office of the Ministry of Law and Human Rights of West Java and the Ministry of Law and Human Rights of the Republic of Indonesia. The 
Ministry of Law and Human Rights is a ministry in the Government of Indonesia that deals with legal and human rights matters.

There has no evaluation been applied to the usage of Management Information System Mobile Application from usability level, so it cannot be ascertained that the application of the "Management Information System Mobile Application" has been effective, efficient and provides user satisfaction with the "The Management Information System Mobile Application". Unlike desktop applications, mobile applications have different architectures and models. Mobile applications have other restrictions that are different from other types of software such as mobile context, connections, small screens, different resolutions, and different entry methods. [4].

Other issue of The Management Information System mobile application is there are many unused features, appropriate placement of feature and icon, and feedback from users who already using it is somewhat unsatisfactory. This problem is part of the usability problem in the level of effectiveness, efficiency and user satisfaction in using applications.

Usability testing is a method of software testing that involves representative software user by giving them the responsibility to perform representative tasks on the initial prototype interface, which aims to improve the quality of the interface by finding deficiencies in the interface that need to be fixed [5].

Usability is used to ensure that mobile applications are not only functional but also easy to use for users [6]. Through Usability Testing, mobile applications will be able to improve many aspects of user interaction with the application, including user satisfaction, learning ability, and effectiveness of use [7].

The similar researches about usability testing have been conducted by Hanifah Muslimah Az-zahra (2015) [8], Satria Utama (2011) [9], Wardhana (2016) [10], Hoehle (2015) [11], Syaifullah (2017) [12], and Fahmi (2018) [13]. Based on the previous findings, they tested effectivity level, efficiency, and user satisfaction.

Based on the above problems the researcher chose the usability testing method with perfromance measurement, usability questionnaire and retrospective think aloud to determine the level of effectiveness, efficiency and user satisfaction when using the Management Information System Mobile Application to complete daily tasks.

Within the issue of usability on Management Information System Mobile Application, the basis of this research is based on:

a. How is the level of effectiveness of using the Management Information System Mobile Application.

b. How is the level of efficiency level of using the Management Information System Mobile Application.

c. How is the user satisfaction toward the using of Management Information System Mobile Application.

Based on the problems above, the aims of this research are:

a. Knowing the level of effectiveness of the Management Information System Mobile Application.

b. Finding out the efficiency of Management Information System Mobile Application.

c. Discovering user satisfaction after using Management Information System Mobile Application.

Based on the problems mentioned above, the writer will conduct a study entitled "Implementation of Usability Testing to Measure The Usability Aspect of Management Information System Mobile Application (Case Study Sukamiskin Correctional Institution)" and limit the problem to:

a. The research use Performance Measurement, Usability Questionnaire dan Retrospective Think Aloud method.

b. The research is limited on the using of Management Information System mobile application.

c. Respondents are categorized as Correctional Institution Sukamiskin jobholder within employee identification number which gained 20 respondents.

\section{Methodology}

The methodology used in evaluating Management Information System Mobile Application uses the usability testing which will be discussed systematically through spesific steps to be used in solving research problems. The research steps are presented on Fig. 1. 


\section{Fig. 1. Research Plot}

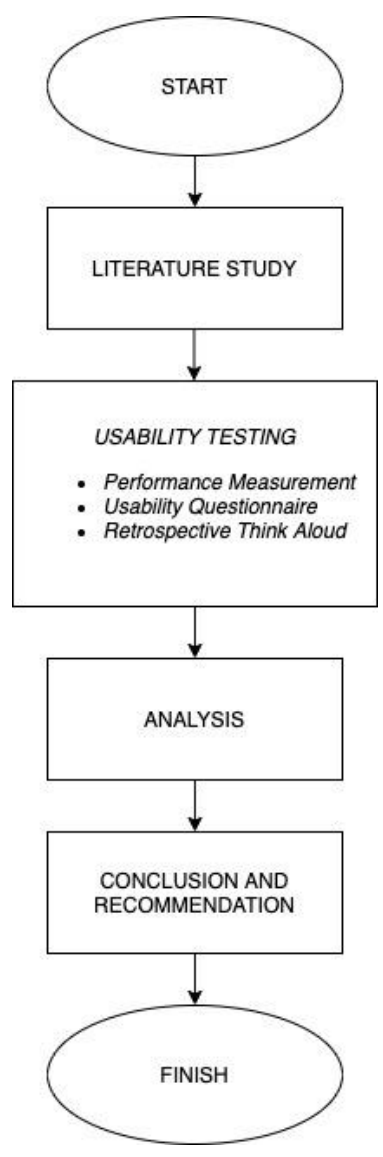

\section{A. Usability}

Usability is a series of activities carried out to measure the evaluation of the efficiency, effectiveness, and satisfaction of software users. Two events can be used in evaluating usability, the first using the opinions of software developers and the second using usability metrics [14]. Usability evaluation is usually able to be defined as a procedure developed by well-defined activities to collect data related to the interaction of end users and software products, to determine the specific piece of software contributing to achieving goals [15]. Usability evaluation is also used for software development [16].

\section{B. Mobile Application}

Mobile application is a set of program that is running on mobile, on specific tasks for user. Mobile application is a new part and develops rapidly on information technology and global communication [17]. Today, mobile application and services are increasingly helping everyday life situations [18].

Mobile applications are also one form of the development of information technology that is useful to help government or private organizations or institutions to get the level of efficiency and effectiveness of the business processes that are run, by using mobile applications users can automatically make transactions or find information quickly by simply using smartphone [4].

\section{Testing Method}

The device used in this study is a smartphone and carried out three types of tests:

\section{- Performance Measurement}

Performance Measurement is a way or technique to measure the level of effectiveness and efficiency of an application when used by users. Effectiveness discusses the level of accuracy and completeness obtained from the user to complete certain tasks and can be obtained by measuring the level of completeness [19]. The measurement of effectivity level is calculated from the task success and failure which has been done by respondents. The formula used is:

$$
\text { Success }=\frac{\text { Number of finished tasks }}{\text { Total number of tasks }} \times 100 \%
$$


The formula to calculate the failure level is:

$$
\text { Failure }=\frac{\text { Number of failed tasks }}{\text { Total number of tasks }} \times 100 \%
$$

\section{- Usability Questionnaire}

Questionnaire is utilized to understand either the user like or dislike the product or system. Questionnaire is addressed to those who have used Management Information System Mobile Application. This testing used Likert Scale on questionnaire given. Likert Scale is psychometric responses are used to obtain agreement from respondents or study participants using statements or a series of statements [20].

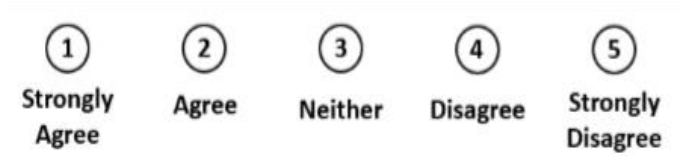

Fig. 2. Likert Scale Example

\section{- Retrospective Think Aloud}

Retrospective Think Aloud (RTA) is one of the usability testing methods that collect the verbalization of user performance after the performance is over. RTA is also an effective method in interface design in detecting usability problems, especially if the designer carries out a usability test by himself and thus gets direct feedback from users [21]. RTA is obtained by giving questionnaires and interviews with respondents. Interviews were conducted to find out the experience of the respondents and to get criticism as well as suggestions related to the overall application. Data from RTA were so analyzed for gaining more understanding of user confustion or complaints on application [22].

\section{Respondents}

Five is generally accepted on usability testing because $80 \%$ of problems were found on 5 persons [23]. The result if too many respondents were tested would not be much different.

Fig. 3 is a curve of how many respondents with number of problems on a product [4]. Nielsen (2000) said that picture 3 showed the test would result in the same way or was not significant when many respondents were obtained.

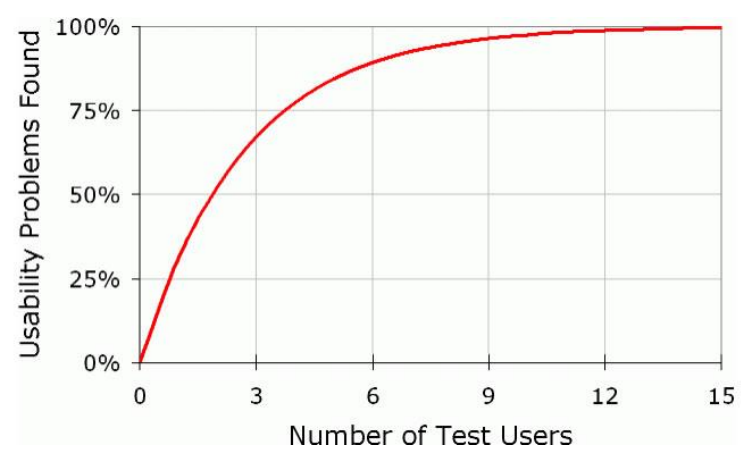

Fig. 3. User Testing Curve

If a test has limited time and funds, using $4-5$ respondents is a good choice because the results of the test can reach $85 \%$ with a condition of 2-3 times tests.

But in this study, involving 20 people in order to do no more than one time testing. All respondents are employees at Sukamiskin Correctional Institution in Bandung.

\section{E. Task Scenario}

Task scenario is an action that is asked to the participant to take interface that is needed to be tested [24]. On Table I below showed that task code and description which were made to be finished by all respondents and have been explained to them the steps of how to do with each task. 
Table I. Task Scenario Description

\begin{tabular}{ll}
\hline Task Code & Task Name \\
\hline $\mathrm{T}-01$ & Login \\
\hline $\mathrm{T}-02$ & Self Attendance \\
\hline $\mathrm{T}-03$ & Leave Application \\
\hline $\mathrm{T}-04$ & Daily Journal \\
\hline
\end{tabular}

\section{F. Testing Procedure}

The respondent is given a set of instructions to complete the existing task scenario using the smartphone they have. After the respondent completes the given task, the respondent is asked to fill in comments when using the Simpeg application. And finally, the respondent answered the item questionnaire questions.

\section{Literature Review}

Hanifah Muslimah Az-Zahra (2015) [8] tested the usability with level of effectivity, efficiency and user satisfaction as parameter. The correlation was found between user experience and usability problem so that the user need to improve more. User satisfaction showed that usability test is highly recommended to be applied on application.

Satria Utama (2011) [9] after tested usability on application interface showed that application is more effective, efficient and increasing user satisfaction on using that application.

Septiyawan Rosetya Wardhana (2016) [10] in considering review of mobile application user the evaluation score is more effective and suitable with usability factor which is review by user.

M. D. Fahmi (2019) [13] in implementing usability testing the participants who worked on the task had a success rate of $82.9 \%$, an efficiency level of $85.2 \%$ and user satisfaction reaching $83.1 \%$.

Ni Luh Putri Ari Wedayanti (2019) [25] the application of the usability method can measure the effectiveness, efficiency and user satisfaction. Based on these tests, providing recommendations based on usability evaluations conducted is expected to increase the level of effectiveness, efficiency and user satisfaction in terms of usage.

\section{Research Method}

On the previous research Hanifah Muslimah Az-Zahra (2015) [8] used Measurement technique to gain more effectivity and efficiency level and insert Moderating Technique which was Concurrent Think Aloud. These techniques collected from tested participants and they were asked to think and tell the examiner about how they feel and think when interacting with application.

Based on research by Satria Utama (2011) [9], the increasing of user interface in more effective, efficient and increasing of user satisfaction gotten from usability evaluation result with Eye Tracking technique.

S. R. Wardhana (2016) [10] revealed sentiment analysis for usability factor evaluation is a usability factor evaluation method that considers orientation and sentiment level in a mobile application user review. By considering the level of sentiment on user reviews, the resulting evaluation scores become more effective and in accordance with the usability factors reviewed by users.

M. D. Fahmi (2019) [13], implemented usability tested with USE Questionnaire technique method since it correlated with parameter on usability technique such Usefullness, Ease of Use. Use Questionnaire method is one of measurement tool to usability value.

Another technique in this research is Retrospective Think Aloud which is one of the techniques of usability testing. In this study the Retrospective Think Aloud technique is used to get the results of the thoughts and feelings of the respondents when using the application and these results correlate with the level of satisfaction of respondents using the mobile application Employee Management Information System Ministry of Law and Human Rights.

\section{Evaluation Result}

\section{A. Performance Measurement}

In this part will show the result of measurement with Performance Measurement technique. This result then is used to measure level of effectivity and efficiency.

a) Effectivity 
Effectivity is calculated from average value based on success and failure of task scenario which is done by respondent. This criterion is measured from the number of failure when using application. The Table II below showed the result of all respondent in doing task given through task scenario. All respondent could finish all task scenario.

Table II. Success Task Scenario

\begin{tabular}{lcccc}
\hline \multirow{2}{*}{ Respondent } & \multicolumn{4}{c}{ Task Scenario } \\
& $\mathrm{T}-01$ & $\mathrm{~T}-02$ & $\mathrm{~T}-03$ & $\mathrm{~T}-04$ \\
\hline All & $100 \%$ & $100 \%$ & $100 \%$ & $100 \%$ \\
\hline
\end{tabular}

\section{b) Error or Failure Level}

Level of respondent error is one of the ways to understand about failure level and respondent error on usability testing. Each defined and tested task when the error is occurring would be counted to gain the score in order to find out the respondent error. The Table III below shows that application user did not encounter any difficulties so that there were no failures during the test.

Table III. Failure Level

\begin{tabular}{lcccc}
\hline \multirow{2}{*}{ Respondent } & \multicolumn{4}{c}{ Task Scenario } \\
\cline { 2 - 5 } & $\mathrm{T}-01$ & $\mathrm{~T}-02$ & $\mathrm{~T}-03$ & $\mathrm{~T}-04$ \\
\hline $\begin{array}{l}\text { All } \\
\text { Respondents }\end{array}$ & $0 \%$ & $0 \%$ & $0 \%$ & $0 \%$ \\
\hline
\end{tabular}

\section{c) Efficiency}

Measuring how fast the user finishes the task and measure with the units of time.

Table IV below shows the results of data processing efficiency and work time on task T-03 shows that the ability to learn the task T-03 is still lacking, indicated by the large amount of time to complete the task. The ability to learn or learnability itself is defined as the ability for all users to operate tasks after interacting with a system [26].

Table IV. Data Processing Efficiency

\begin{tabular}{|c|c|c|c|c|c|}
\hline \multirow[b]{2}{*}{ Respondent } & \multicolumn{4}{|c|}{ Task Scenario } & \multirow[b]{2}{*}{ Average } \\
\hline & $\begin{array}{l}\mathrm{T}- \\
01\end{array}$ & $\begin{array}{l}\mathrm{T}- \\
02\end{array}$ & $\begin{array}{l}\mathrm{T}- \\
03\end{array}$ & $\begin{array}{l}\mathrm{T}- \\
04\end{array}$ & \\
\hline R1 & 0.17 & 0.10 & 2.41 & 1.15 & 0.89 \\
\hline R2 & 0.25 & 0.16 & 3.14 & 1.32 & 1.21 \\
\hline R3 & 0.15 & 0.8 & 2.10 & 1.09 & 1.03 \\
\hline R4 & 0.16 & 0.7 & 2.11 & 1.09 & 1.01 \\
\hline R5 & 0.15 & 0.9 & 2.12 & 1.12 & 1.07 \\
\hline R6 & 0.15 & 0.7 & 2.14 & 1.10 & 1.02 \\
\hline R7 & 0.17 & 0.10 & 2.23 & 1.13 & 0.9 \\
\hline $\mathrm{R} 8$ & 0.18 & 0.9 & 2.29 & 1.19 & 1.14 \\
\hline R9 & 0.15 & 0.8 & 2.13 & 1.11 & 1.04 \\
\hline R10 & 0.17 & 0.10 & 2.22 & 1.14 & 0.9 \\
\hline R11 & 0.16 & 0.12 & 2.14 & 1.14 & 0.89 \\
\hline R12 & 0.20 & 0.14 & 3.08 & 1.30 & 1.18 \\
\hline R13 & 0.18 & 0.9 & 2.23 & 1.17 & 1.17 \\
\hline R14 & 0.16 & 0.9 & 2.10 & 1.09 & 1.06 \\
\hline $\mathrm{R} 15$ & 0.17 & 0.10 & 2.23 & 1.14 & 0.91 \\
\hline R16 & 0.16 & 0.10 & 2.19 & 1.11 & 0.89 \\
\hline R17 & 0.16 & 0.13 & 2.18 & 1.13 & 0.9 \\
\hline R18 & 0.18 & 0.12 & 2.24 & 1.17 & 0.92 \\
\hline R19 & 0.19 & 0.14 & 2.26 & 1.17 & 0.94 \\
\hline R20 & 0.15 & 0.8 & 2.12 & 1.12 & 1.13 \\
\hline Average & 0.19 & 0.44 & 2,27 & 1,16 & 1.01 \\
\hline
\end{tabular}




\section{B. Questionnaire}

Furthermore, data about the satisfaction of respondents in completing all tasks were obtained from a questionnaire that was given after the respondent completed all the tasks. Questionnaires are used to ensure questions given to respondents are the same, and responses are easily obtained quickly. Each respondent was asked to fill in each item, and each question had five answer points that were assessed using a Likert scale. By using a Likert scale we can distinguish arguments on each item [27].

The Likert scale uses a number of odd responses that can allow respondents to give positive, neutral or negative choices. After that information obtained using a five-point Likert scale can be easily collected and analyzed. Table V below shows the results of the task satisfaction questionnaire using a five-point Likert scale.

Table V. Task Satisfaction Questionnaire

\begin{tabular}{ccccccc}
\hline Question & $\begin{array}{c}\text { Task } \\
\text { Code }\end{array}$ & $\begin{array}{c}\text { Strongly } \\
\text { Agree }\end{array}$ & Agree & Neutral & Disagree & $\begin{array}{c}\text { Strongly } \\
\text { Disagree }\end{array}$ \\
\hline $\begin{array}{c}\text { Is it easy to do the login } \\
\text { process? }\end{array}$ & T-01 & 7 & 7 & 3 & 1 & 2 \\
\hline $\begin{array}{c}\text { Is the self-absence } \\
\text { process easy to do? }\end{array}$ & T-02 & 12 & 3 & 2 & 2 & 1 \\
\hline $\begin{array}{c}\text { Is it easy to apply for } \\
\text { leave? }\end{array}$ & T-03 & 7 & 5 & 3 & 4 & 1 \\
\hline $\begin{array}{c}\text { Is it easy to fulfill the } \\
\text { daily journal? }\end{array}$ & T-04 & 7 & 4 & 5 & 3 & 1 \\
\hline
\end{tabular}

\section{Retrospective Think Aloud}

Retrospective Think Aloud is used to measure user satisfaction while using application. The result can be seen on the Table VI below.

Tabel VI. Retrospective Think Aloud Data Result

\begin{tabular}{|c|c|c|}
\hline Respondent & Difficulties & Suggestions \\
\hline R3 & $\begin{array}{c}\text { The colour of login backgrounf is too } \\
\text { striking } \\
\text { There so many hidden leave } \\
\text { application features }\end{array}$ & $\begin{array}{l}\text { Change the background colour } \\
\text { The application icon is shown on the } \\
\text { main page }\end{array}$ \\
\hline R4 & $\begin{array}{l}\text { Too many icon of unused features } \\
\text { Each icon is to close }\end{array}$ & $\begin{array}{c}\text { To change the icon with the feature } \\
\text { is more used } \\
\text { To change icon location }\end{array}$ \\
\hline R5 & $\begin{array}{l}\text { It is difficult to fulfill the Daily } \\
\text { Journals that every employee who has } \\
\text { more than } 1 \text { job description must } \\
\text { return to the previous page to choose } \\
\text { the next job description }\end{array}$ & $\begin{array}{l}\text { The journal entry settings are } \\
\text { rearranged so that employees can } \\
\text { more easily fill in their daily journals }\end{array}$ \\
\hline R11 & $\begin{array}{l}\text { There are too many forms to be filled } \\
\text { on feature to cause more long time to } \\
\text { do the task }\end{array}$ & $\begin{array}{l}\text { To simplify the feature or to cut } \\
\text { number of forms }\end{array}$ \\
\hline R15 & $\begin{array}{l}\text { Too many features and those confused } \\
\text { the user, many tasks need more time } \\
\text { just to look for the feature }\end{array}$ & $\begin{array}{l}\text { It is better to provide favourite menu } \\
\text { to unite the most used features by the } \\
\text { user }\end{array}$ \\
\hline
\end{tabular}




\section{Discussion}

\section{A. Effectiveness}

A product is effective if there are $70 \%$ of user could finish the task[24]. Based on usability testing result, Employee Management Information System Ministry of Law and Human Rights has been proven effective. As can be seen on table 2 that all respondents are able to finish the given task.

\section{B. Error Atau Failure Level}

Based on table III, the failure level of respondents who followed the Usability Testing application Employee Management Information System Ministry of Law and Human Rights the value of the failure level of respondents was $0 \%$. This shows that none of the respondents experienced failure on every given task. Based on this failure level it can also be concluded that all respondents were able to learn the tasks assigned and the application of the Employee Management Information System Ministry of Law and Human Rights was fairly effective when used by respondents.

\section{Efficiency}

On task T-03 the respondent's ability is still not fast compared to completing other tasks. This low learning ability can be influenced by previous assignments [28]. According to previous research, it will take less than 2 minutes to study the application [29].

Based on table IV, the average respondent completed the T-03 assignment over 2 minutes, this result shows that the level of study ability of the respondents is still low compared to completing other tasks. The low learnability in completing tasks on a mobile application is influenced by human habits in using smartphones [30].

\section{Satisfaction}

Based on the result of questionnaire given to the respondent, which can be seen on table V, it can be concluded that respondents have been satisfied with Management Information System Mobile Application. All respondents understand and quickly learn the usage of this application.

This experience is influenced the answer of questionnaire that has positive subjectivity. The element of positive subjectivity is considered to be in a greater scope than usability itself. This scope is the user experience [31]. Therefore the satisfaction found is for the user experience and not usability.

\section{E. Retrospective Think Aloud}

Based on Retrospective Think Aloud data found the problem stated in table VI that too many icons and hidden features make respondents need more time to complete their tasks. This is in line with previous research which states many of the usability problems identified are related to mistakes made during tests [32].

\section{Conclusion}

Based on the results of research and analysis that have been evaluated aspects of usability in the Management Information System Mobile Application using the usability testing method, it can be concluded that the level of effectiveness and satisfaction is good. Based on table II, the level of effectiveness obtained from all respondents able to complete all the tasks given, reached $100 \%$ success. The failure rate according to table III shows that none of the respondents experienced a failure while completing the given tasks. Overall respondents gave a satisfied value after using the Management Information System Mobile Application. Based on the results of the questionnaire given, all respondents were able to understand the application of the Employee Management Information System Ministry of Law and Human Rights and can learn the application.

After testing, there are problems with the speed of the respondents in completing their tasks. This affects the value of the resulting efficiency. The average respondent needs more time to learn the tasks given to complete the tasks. This needs to be improved again to improve the efficiency of the Management Information System Mobile Application.

Meanwhile, another problem is Retrospective Think Aloud, that there are number of features and icons displayed on the screen that confuse some respondents. In addition there are also some hidden features that make respondents need more time to search first before they successfully completes the task. But overall respondents have expressed satisfaction using the Management Information System Mobile Application.

In conclusion, this study contributes to the Management Information System in its use through Usability testing. The results showed that using performance measurements and retrospective think aloud techniques had a significant effect on user satisfaction in sukamiskin correctional institution. With these techniques also shows the level of employee ability to complete tasks in the application does not fail. Researchers get benefit both material and time, because the usability questionnaire can be done online, can be witness directly assessing the level of effectiveness and efficiency of respondents while working on the tasks given. And by using performance measurement, usability questionnaire and retrospective think aloud techniques can be more feasible for researcher and respondents who are not 
charged any fees. Also, it will help software developers to understand how users interact with applications. This can also be used as a benchmark for mobile applications in other government agencies or institutions with similar features.

The limitation of this study is that respondents who use the Management Information System Mobile Application in Sukamiskin Lapas are in the age range of 20 to 33 years because employees in Sukamiskin Lapas are still relatively new and young employees. Further research could use various age of respondents and grouped between beginners and professionals who are accustomed to using mobile applications.

\section{References}

[1] M. G. Arsawiguna, A. A. K. Agung, C. Wiranatha, dan K. S. Wibawa, "Rancang Bangun Aplikasi Game Tajen Berbasis Android menggunakan Artificial Intelligence", Lontar Komputer, vol. 6, no. 2, hal. 84-95, 2015.

[2] I. P. P. Andika, P. A. Bayupati, dan N. K. A. Wirdani, "Rancang Bangun Aplikasi Pendeteksi Tipe dan Nilai Resistor Berbasis Android", Lontar Komputer, vol. 6, no. 1, hal. 529-540, 2015.

[3] Dae-Ho Byun, "Evaluating usability, user satisfaction and intention to revisit for successful e-government websites", 2011.

[4] Nielsen, J. (2000). Why you Only Need to Test with 5 Users. Jakob Nielsens Alertbox, 19(September 23), 1-4.

[5] Lazar, J., Feng, J. H. \& Hochheiser, H. "Research Methods in Human-Computer Interaction $2^{\text {nd }}$ edition", Morgan Kaufmann, Cambridge (2017).

[6] R. Baharuddin, D. Singh, D and R. Razali, R, Usability Dimensions for Mobile Applications-A Review. Research Journal of Applied Sciences, Engineering and Technology, 5(6), 2013, pp. 2225-2231.

[7] H. Hoehle and V. Venkatesh, V, Mobile Application Usability: Conceptualization and Instrument Development. MIS Quarterly, 39(2), 2015, pp. 435-472.

[8] H. M. Az-zahra, A. Pinandito, and H. Tolle, Usability Evaluation of Mobile Application in Culinary Recommendation System. 2015.

[9] S. Utama, Perbaikan User Interface Halaman Internet Banking dengan Metode Usability Testing. 2011.

[10] S. R. Wardhana, D. Purwitasari, dan S. Rochimah, Analisis Sentimen pada Review Pengguna Aplikasi Mobile untuk Evaluasi Faktor Usability. 2016.

[11] H. Hoehle dan V. Venkatesh, Mobile Application Usability: Conceptualization and Instrument Development, 2015.

[12] D. H. Syaifullah, M. A. Puspasari, dan A. Hanifah, Analisis User Experience pada Penggunaan Aplikasi Mobile Jakarta Smart City. 2017.

[13] M. D. Fahmi, H. M. Az-zahra, dan R. K. Dewi, Perbaikan Usability Aplikasi Pemesanan Tiket Bioskop Menggunakan Metode Usability Testing dan USE Questionnaire. 2018.

[14] Tullis, Tom, and Albert, Bill. 2008. Measuring The User Experience. Morgan Kauffman.

[15] A. Fernandez, E. Insfran, and S. Abrahao, "Usability evaluation methods for the web: A Systematic mapping study," Inf. Softw. Technol., vol. 53, pp. 789-817, 2011.

[16] F. Paz and J. A. Pow-Sang, "A systematic mapping review of usability evaluation methods for software development process," Int. J. Sotw. Eng. Its Appl., vol. 10, no. 1, pp. 165-178, 2016.

[17] M. G. Zaragoza, H. Kim, and D. S. Han, "Mobile Application Development, Approaches, Advancement and Process," vol. 10, no. 10, pp. 79-88, 2016.

[18] K. Wac, S. Ickin, J.-H. Hong, L. Janowski, M. Fiedler, and A. K. Dey, "Studying the Experience of Mobile Applications Used in Different Context of Daily Life Categories and Subject Descriptors," Proc. first ACM SIGCOMM Work. Meas. Up stack, pp. 7-12, 2011.

[19] Singun, A. P. Usability Metrics for a Web-Based Test Blueprint System. Journal of Engineering and Applied Sciences, 12: 6898-6903. Medwell Journals, Faisalabad (2017)

[20] Betram, D.: Likert Scale. 2016

[21] Jorgensen, S., \& Marthandan, G. (2010). Thinking-aloud in user interface design: a method promoting cognitive ergonomics. Ergonomics, vol. 33, no. 4, pp. 501-507.

[22] E. Geisenand J.R. Bergstrom, Usability Testing for Survey Research. Chennai: Elsevier. 2017.

[23] C.M. Barnum, N. Bevan, G. Cockton, J. Nielsen, J. Spool, and D. Wixon, The "Magic Number 5": Is It Enough for Web Testing?. CHI '03 Extended Abstracts on Human Factors in Computing Systems, Ft. Lauderdale, California: ACM. 2003, pp. 698-699.

[24] J. Nielsen, Usability Engineering. Mountain View, California: Morgan Kaufmann. 1993.

[25] N. L. P. A. Wedayanti, N. K. A. Wirdiani, I. K. A. Purnawan, Evaluasi Aspek Usability pada Aplikasi Simalu Menggunakan Metode Usability Testing. 2019.

[26] J. Rubin and D. Chisnell, Handbook of Usability Testing: How to Plan, Design, and Conduct Effective Tests $2^{\text {nd }}$ edition. Indianapolis, Indiana: Wiley Publishing, Inc. 2008.

[27] Fung, R. H. Y.*, Chiu, D. K. W., Ko, E. H. T.*, Ho, K. K., \& Lo, P. (2016). Heuristic Usability Evaluation of University of Hong Kong Libraries' Mobile Website. The Journal of Academic Librarianship, in press.

[28] T. Tullis, and W. Albert, Measuring the User Experience: Collecting, Analyzing, and Presenting Usability Metrics (Interactive Technologies), $2^{\text {nd }}$ edition. Massachusetts: Elsevier. 2013.

[29] R. Harrison, D. Flood, and D. Duce, Usability of mobile applications: literature review and rationale for a new usability model. Journal of Interaction Science, 1(1), 2013, pp. 1-16.

[30] T. Neil, Mobile Design Pattern Gallery: UI Patterns for Smartphone Apps. Sebastopol: O’Reily Media. 2014.

[31] M. Hassenzahl, and N. Tractinsky, User Experience: a research agenda. Behaviour and Information Technology, 25(2), 2006, pp. 91-97. 
[32] A. W. Kushniruk, M. M. Triola, E. M. Boryckic, B. Steind, and J. L. Kannrye, Technology induced error and usability: The relationship between usability problems and prescription errors when using a handheld application. International Journal of Medical Informatics, 74(1), 2005, pp. 519-526.

\section{Authors' Profiles}

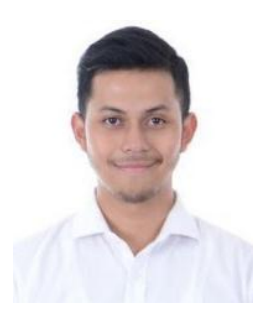

Hafidz. Firdaus Student of Informatics Major, Faculty of Engineering of Widyatama University.

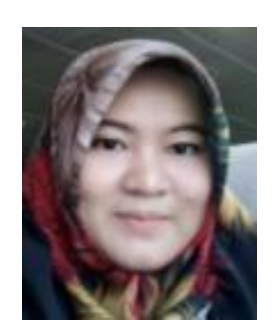

Azizah. Zakiah Lecturer of Informatics Major, Faculty of Engineering of Widyatama University.

How to cite this paper: Hafidz. Firdaus, Azizah. Zakiah, " Implementation of Usability Testing Methods to Measure the Usability Aspect of Management Information System Mobile Application (Case Study Sukamiskin Correctional Institution)", International Journal of Modern Education and Computer Science(IJMECS), Vol.13, No.5, pp. 58-67, 2021.DOI: 10.5815/ijmecs.2021.05.06 